\title{
ГАЛУЗЕВЕ МАШИНОБУДУВАННЯ
}

УДК 678.059

DOI https://doi.org/10.32838/2663-5941/2021.4/02

Панасюк I.B.

Київський національний університет технологій та дизайну

Залюбовський М.Г.

Відкритий міжнародний університет розвитку людини «Україна»

\section{ЕКСПЕРИМЕНТАЛЬНЕ ДОСЛІДЖЕННЯ ФІЗИКО-МЕХАНІЧНИХ ВЛАСТИВОСТЕЙ ПОЛІМЕРНИХ МАТЕРІАЛІВ У СЕРЕДОВИЩІ НИЗЬКИХ ТЕМПЕРАТУР (ЧАСТИНА 1: ВИЗНАЧЕННЯ ТЕМПЕРАТУРИ КРИХКОСТІ)}

Значна частина формованих деталей різних галузей промисловості, в тому числі легкої промисловості, вироблясться з еластичних полімерних матеріалів способом лиття. Після чого такі типи деталей потребують виконання трудомісткої фінішної галтувальної обробки, у ході виконання якої реалізується відділення відлитих деталей від їх ливників. Однак обробка деталей в ємкостях з різним характером руху (обертальні барабани, ємкості, котрі здійснюють планетарний або складний просторовий рух тощо) за допомогою ударного впливу за кімнатної температури неможлива через високу еластичність матеріалів. У разі зниження температури еластичність полімерів зменшується, а у разі досягнення температури крихкості вони поводяться як крихкі матеріали і руйнуються за величини відносної деформації менше 10\%. Ударна дія на охолоджені деталі призводить до руйнування найменш міцних їх елементів - облоя, ливників. Охолодження деталей здійснюється різними способами: введенням у зону обробки холодоагенту у вигляді двоокису вуглецю (рідкого або твердого), рідкого азоту або шллхом охолодження камери з робочим середовищем за допомогою холодильної установки. Значні переваги має рідкий азот. Він забезпечує охолодження до температури $-195,8^{\circ} \mathrm{C}$, подача його в зону обробки не являє складнощів, він нешкідливий для навколишнього середовища. Застосування рідкого азоту дозволяє скоротити час обробки, підвищити якість та одночасно знизити вартість обробки. Для можливості успішного застосування в легкій промисловості иьього методу обробки деталей були проведені експериментальні дослідження крихкості найбільш часто використовуваних полімерних матеріалів, а також експериментальні дослідження визначення енергії удару, необхідної для руйнування облоя. Результати досліджень можуть бути використані на стадії проєктування відповідних технологічних прочесів обробки полімерних деталей.

Ключові слова: полімер, температура крихкості, рідкий азот, робоча ємкість.

Постановка проблеми. Відділення деталей від ливників у галтувальному обладнанні [1, с. 8-10] (галтувальні барабани, планетарно-відцентрові машини, машини зі складним просторовим рухом ємкостей тощо) реалізується за рахунок зіткнення рухомих деталей між собою, зі стінками ємкості та $з$ частками наповнювача (якщо він використовується) [2, с. 19-22; 3 с. 48-54]. Така обробка ефективна, коли деталі виготовлені з крихких матеріалів, які легко руйнуються у разі ударної взаємодії.

Деталі, виготовлені 3 полімерних матеріалів, також можуть успішно оброблятися в галтувальному обладнанні за умови охолодження до стану крихкого руйнування [4, с. 20-100]. Стан крихкого руйнування полімери досягають у разі охолодження до температури крихкості. Зниження до температури крихкості полімерів призводить до унеможливлення виникнення високоеластичних деформацій, полімер руйнується як крихке тіло за відносно незначної величини деформації $(<10 \%)$ [5, с. 5-85].

Товщина та маса облоя, задирок, ливників незначні порівняно із самим виробом, тому у разі охолодження ці елементи найкраще промерзають та досягають крихкого стану за більш короткий проміжок часу ніж сам виріб і у разі подальшої механічної обробки в галтувальних барабанах 
легко видаляються з поверхні деталей, не пошкоджуючи їх. Для успішного застосування цього методу обробки в легкій промисловості необхідно володіти інформацією щодо ряду фізикомеханічних властивостей полімерних матеріалів у середовищі низьких температур, зокрема знати: температуру крихкості матеріалу; енергію удару, необхідну для руйнування облоя; тривалість промерзання облоя і деталі до заданої температури.

Постановка задачі. Мета цієї роботи - експериментальне дослідження визначення температури крихкості та енергії руйнування еластичних полімерних матеріалів у середовищі низьких температур.

Виклад основного матеріалу досліджень.

Визначення температури крихкості. Дослідження проводили на експериментальній установці, кінематична схема якої представлена на рис. 1. Установка складається зі столу 1 , на якому встановлено посудину Дьюара 2 з рідким азотом, механізм опускання зразка, що складається 3 опори, що містить направляючу втулку 3 , штока 4 із затискачем. Шток підпружинений та утримується в піднятому стані фіксатором 5, з'єднаним 3 мікровимикачем 6. На столі встановлено ударний механізм, який включає ударник 7 бойком, корпус 8 , ударну пружину 9, фіксатор 10 та електромагніт 11. Ударний механізм змонтований на столі за допомогою регульованої опори 12.

Під час проведення досліджень температуру в зоні охолодження виміряли за допомогою спеціально виготовлених термопар мідь-константан. Градуювання термопар виконували відомими методами [6, с. 58-225]. Вимірювання здійснювали мілівольтметром з цифровою індикацією.

Досліджували такі полімерні матеріали: гуму стироніп ОСТ 17-226-73; пористий поліуретан фірми "Hansman" (рідке формування); монолітний поліуретан “Avalon" фірми "Hansman' (рідке формування); термопластичний монолітний поліуретан "Elastolan" фірми "Elastogran" (BASF) (лиття під тиском); 50\% -ву суміш первинного і вторинного поліетилену високого тиску ТУ 6-05-1853-78; поліамід вторинний ТУ 6-13-88.

Температуру крихкості зразків визначали за стандартною методикою [7, с. 5-270]. Розміри зразків: довжина $-25 \pm 0,5$ мм, ширина $6,5 \pm 0,3$ мм, товщина $-2 \pm 0,3$ мм. Для однієї серії дослідів відбирали 10-15 однакових зразків. Дослідження проводилися в такій послідовності: посудину Дьюара заповнювали рідким азотом, зразок закріплювався в затискачу установки так, щоб забезпечувалася його нерухомість, але не створювалася надмірна концентрація напружень сильним стисненням. Потім він опускався в посудину з рідким азотом до рівня, на якому досягалася необхідна температура. Охолодження тривало 7 хвилин. При цьому коливання температури не перевищували $\pm 1^{\circ}$ С. Регулювання температури досягалося шляхом переміщення вгору або вниз штока із закріпленим зразком i термопарою, яка реєструвала температуру в зоні охолодження. Через 7 хвилин зразок піднімався в крайнє верхнє положення, після чого по ньому виконувався механічний удар бойком. Якщо зразок зберігав цілісність, його заміняли та наступний досліджували аналогічним шляхом за температури на $10^{\circ} \mathrm{C}$ нижче за первинну. У разі руйнування зразка температуру підвищували приблизно на $10^{\circ} \mathrm{C}$. Тим самим встановлювали інтервал температури крихкості. Потім визначали шукане значення температури, досліджуючи кожен раз нові зразки, послідовно зменшуючи на $3^{\circ}-5^{\circ} \mathrm{C}$ інтервал температур. Температуру крихкості встановлювали 3 точністю $\pm 1^{\circ} \mathrm{C}$. За температури, рівної температурі крихкості, досліджували ще два зразки. Результатом випробування вважали найвищу температуру, за якої обидва зразки ставали крихкими. Результати випробувань полімерних матеріалів 3 визначення температури крихкості представлені в таблиці 1.

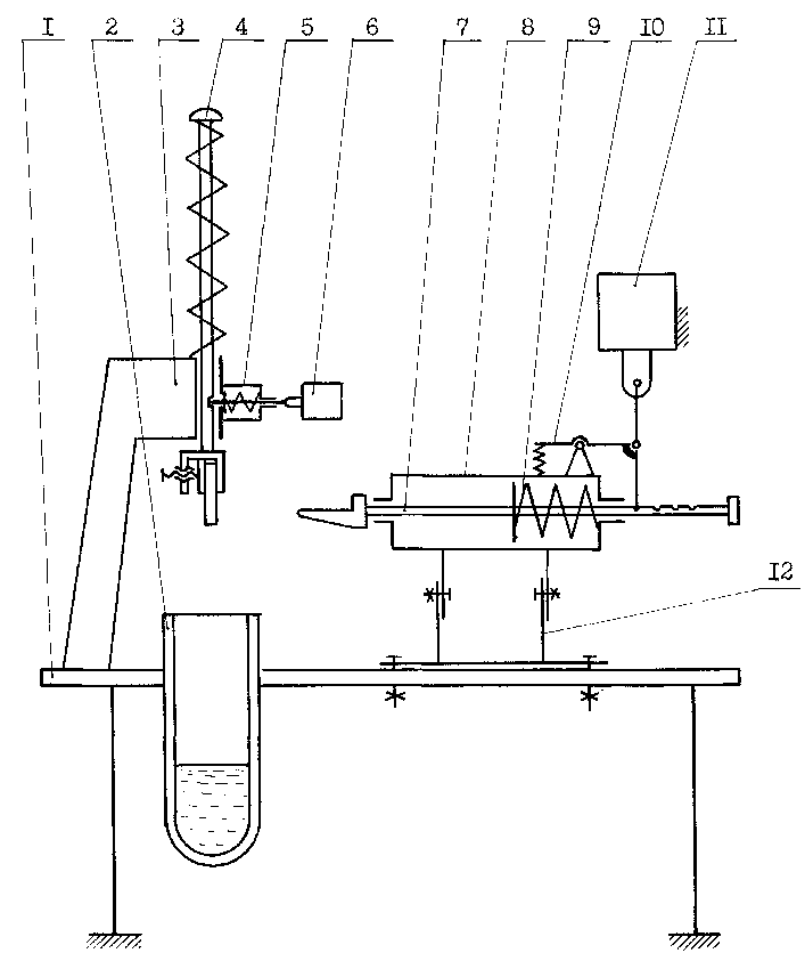

Рис. 1. Кінематична схема експериментальної установки для дослідження фізико-механічних властивостей полімерних матеріалів у середовищі низьких температур 
Таблиця 1

Результати випробувань полімерних матеріалів з визначення температури крихкості

\begin{tabular}{|c|c|c|}
\hline № & Матеріал & $\begin{array}{c}\text { Тем-ра } \\
\text { кр-сті, }\end{array}$ \\
\hline 1 & Гума стироніп ОСТ 17-226-73 & -110 \\
\hline 2 & $\begin{array}{c}\text { Пористий поліуретан (рідке } \\
\text { формування) }\end{array}$ & -55 \\
\hline 3 & $\begin{array}{c}\text { Монолітний поліуретан (рідке } \\
\text { формування) }\end{array}$ & -105 \\
\hline 4 & $\begin{array}{c}\text { Термопластичний монолітний } \\
\text { поліуретан (лиття під тиском) }\end{array}$ & -105 \\
\hline 5 & $\begin{array}{c}\text { 50\%-ва суміш первинного і } \\
\text { вторинного поліетилену високого } \\
\text { тиску ТУ 6-05-1853-78 }\end{array}$ & -113 \\
\hline 6 & Поліамід вторинний ТУ 6-13-3-88 & -43 \\
\hline
\end{tabular}

Визначення енерхії руйнування. Для виявлення енергії руйнування заморожених зразків було проведено калібрування ударного механізму установки. Пружина ударного механізму мала 14 положень у зведеному (стисненому) стані, які відповідають різним енергіям руйнування. Деформація могла змінюватися в діапазоні $X_{n p}=(1 \ldots 14)^{*} 10^{-2}$ м 3 інтервалом в $1 * 10^{-2}$ м. Енергію деформованої пружини розраховували за допомогою виразу:

$$
E=\int_{X_{0}}^{X_{k}} k_{n p} X d X,
$$

де $k_{n p}$ - жорсткість пружини; $X$ - величина деформації пружини.

Величина деформації пружини у зведеному стані:

$$
X_{k}=X_{0}+X_{n p},
$$

де $X_{n p}-$ величина деформації у разі зведення пружини; $X_{0}=15^{*} 10^{-3} \mathrm{M}-$ величина попередньої деформації пружини.

Енергія деформованої пружини ударного механізму змінювалася в межах $E_{n p}=0,04 \ldots 2,3$ Дж. Швидкість деформації пружини визначається за формулою [8, с. 250]:

$$
V_{n}=\sqrt{\frac{2 E_{n p}}{m_{6}}}
$$

де $m_{\sigma}=0,237$ кг - маса бойка.

Калібрувальні параметри ударного механізму експериментальної установки представлені в таблиці 2.

Випробування проводили зі зразками різної товщини. Були підготовлені пластинки (з усіх досліджуваних матеріалів) таких геометричних розмірів: товщина $\delta_{o \sigma}=(1 ; 2 ; 3 ; 5) * 10^{-3} \mathrm{M}$, ширина $b_{o \sigma}=4 * 10^{-3} \mathrm{M}$.
Для різних зразків у процесі експерименту було визначено енергію їх руйнування у разі охолодження до температури крихкості за мінімальної деформації ударної пружини, достатньої для руйнування зразка.

Таблиця 2

Калібрувальні параметри ударного механізму експериментальної установки

\begin{tabular}{|c|c|c|c|}
\hline$X_{n p} 10^{2} \mathrm{M}$ & $X_{\kappa} 10^{2} \mathrm{M}$ & $E_{n p}$, Дж & $V_{n}, \mathrm{M} / \mathrm{c}$ \\
\hline 1 & 2,5 & 0,038 & 0,5 \\
\hline 2 & 3,5 & 0,095 & 0,90 \\
\hline 3 & 4,5 & 0,171 & 1,20 \\
\hline 4 & 5,5 & 0,266 & 1,50 \\
\hline 5 & 6,5 & 0,380 & 1,79 \\
\hline 6 & 7,5 & 0,513 & 2,08 \\
\hline 7 & 8,5 & 0,665 & 2,37 \\
\hline 8 & 9,5 & 0,836 & 2,66 \\
\hline 9 & 10,5 & 1,026 & 2,94 \\
\hline 10 & 11,5 & 1,235 & 3,23 \\
\hline 11 & 12,5 & 1,436 & 3,51 \\
\hline 12 & 13,5 & 1,710 & 3,80 \\
\hline 13 & 14,5 & 1,976 & 4,08 \\
\hline 14 & 15,5 & 2,26 & 4,36 \\
\hline
\end{tabular}

Випробування проводилися таким чином: зразок закріплювали в затискачі установки, забезпечуючи його нерухомість, але не створюючи надмірної концентрації напружень сильним стисненням. Потім його опускали в посудину з рідким азотом до досягнення температури, що відповідає температурі крихкості матеріалу зразка. Охолоджували упродовж 7 хвилин. При цьому коливання температури не перевищували $\pm 1^{\circ} \mathrm{C}$. Ударний механізм зводився до середнього положення. Регулювання температури охолодження досягалося переміщенням штока вгору або вниз. Після закінчення 7 хвилин зразок піднімали в крайне верхнє положення, спрацьовував ударний механізм, здійснюючи удар по зразках. Якщо зразок зберігав цілісність, його заміняли на наступний і випробування повторювали, збільшивши стиснення ударної пружини. Таким чином, визначали мінімальний ступінь стиснення ударної пружини, за якого енергії було досить для руйнування зразка. Результатом випробувань вважали найменше значення стиснення ударної пружини, за якого відбувалося руйнування зразка.

Розкид механічних властивостей зразків полімерів виявився досить значний (наприклад, для зразків поліаміду товщиною $1,0-10^{-3} \mathrm{M}$ енергія руйнування коливалася в межах $0,84 \ldots 1,24$ Дж, для зразків поліетилену товщиною $2-10^{-3}$ м $0,50 \ldots 0,84$ Дж), тому була проведена статистична 
обробка та апроксимація отриманих результатів досліджень. Залежність енергії руйнування зразків від їх товщини для різних полімерних матеріалів описується такими емпіричними рівняннями:

- поліамід вторинний:

$$
E_{n p}=78,75 \delta_{\text {об }} ;
$$

- термопластичний монолітний поліуретан (лиття під тиском):

$$
E_{n p}=56,19 \delta_{o \sigma} ;
$$

- монолітний поліуретан (рідке формування):

$$
E_{n p}=46,15 \delta_{\text {об }} ;
$$

- суміш первинного і вторинного поліетилену високого тиску:

$$
E_{n p}=35,92 \delta_{\text {об }} ;
$$

- пористий поліуретан (рідке формування):

$$
E_{n p}=17,12 \delta_{\text {об̆}} ;
$$

- гума «стироніп»:

$$
E_{n p}=15,42 \delta_{\text {об. }} .
$$

У результаті побудовані графічні залежності енергії руйнування зразків від їх товщини для різних полімерних матеріалів (рис. 2). На рис. 2: 1 - поліамід вторинний; 2 - термопластичний монолітний поліуретан (лиття під тиском); 3 - монолітний поліуретан (рідке формування); 4 - суміш первинного і вторинного поліетилену високого тиску; 5 - пористий поліуретан (рідке формування); 6 - гума «стироніп».

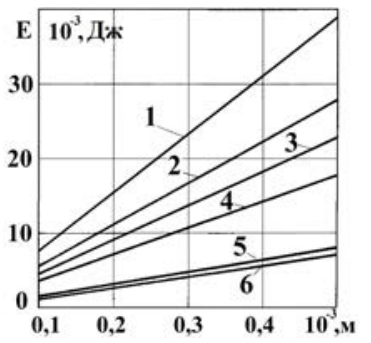

Рис. 2. Залежність енергії руйнування $\boldsymbol{E}_{n p}$ полімерних матеріалів від їх товщини $\delta_{o б}$

Таким чином, отримані дані будуть корисні для виконання оздоблювально-зачисної обробки у середовищі низьких температур деталей, відформованих з полімерів, які широко застосовуються у легкій промисловості.

Висновки. Експериментально визначена температура крихкості досліджуваних матеріалів легкої промисловості (гума «стироніп», пористий та монолітний поліуретани, поліетилен високого тиску, вторинний поліамід). Температура крихкості перебуває в діапазоні $-43-113^{\circ} \mathrm{C}$ та визначає температурний режим обробки деталей, виготовлених з цих полімерних матеріалів.

Доведено, що енергія ударної дії на облой, що забезпечує його видалення, повинна бути в межах $5 * 10^{-3}-39 * 10^{-3}$ Дж і залежить від матеріалу та товщини ділянок, які підлягають видаленню.

Визначено час охолодження деталей до повного промерзання облоя, який становить $1 \ldots 1,5$ хв.

\section{Список літератури:}

1. Залюбовський М.Г., Панасюк І.В., Малишев В.В. Перспективні технології обробки деталей і змішування сипких речовин у рухомих робочих ємкостях (частина 2: типи обладнання з рухомими ємкостями). Вчені записки Таврійського національного університету імені В.І. Вернадського. Серія: технічні науки. 2020. № 3, том 31 (70). С. 7-13.

2. Залюбовський М.Г., Панасюк І.В., Малишев В.В. Експериментальне визначення енергії, необхідної для відділення металевих деталей від ливників. Вісник Київського національного університету технологій та дизайну. 2019. № 5 (138). С. 17-26.

3. Залюбовський М.Г., Панасюк І.В., Малишев В.В. Машини зі складним рухом робочих ємкостей для обробки полімерних деталей : монографія. Київ : Університет «Україна», 2018. 228 с.

4. Копин В.А., Макаров В.Л., Ростовцев А.М. Обработка изделий из пластмасс. Москва : Химия, 1988. 176 с.

5. Бурмістенков О.П. Виробництво литих деталей та виробів 3 полімерних матеріалів у взуттєвій та шкіргалантерейній промисловості. Хмельницький : ХНУ, 2007. 255 с.

6. Орлова М.П., Погорелова О.Ф., Улыбин С.А. Низкотемпературная термометрия. Москва : Энергоатомиздат, 1987. $280 \mathrm{c}$.

7. Тернер С. Механические испытания пластмасс. Москва : Машиностроение, 1979. 278 с.

8. Пономарев С.Д., Андреева Л.Е. Расчет упругих элементов машин и приборов. Москва : Машиностроение, $1980.326 \mathrm{c.}$

\section{Panasyuk I.V., Zalyubovskyi M.G. EXPERIMENTAL STUDY OF THE PHYSICAL AND MECHANICAL PROPERTIES OF POLYMER MATERIALS IN A LOW TEMPERATURE ENVIRONMENT (PART 1: DETERMINATION OF THE BRITTLE TEMPERATURE)}

A significant part of the molded parts of various industries, including light industry, are made from elastic polymer materials by casting. In the future, these types of parts need to perform labor-intensive finishing 
tumbling, during the execution of which the separation of the cast parts from their sprues is realized. The processing of parts in containers with different patterns of motion (rotary drums, containers performing planetary or complex spatial motion, and others) using impact action at room temperature is impossible due to the high elasticity of materials. With a decrease in temperature, the elasticity of polymers decreases, and when the brittleness temperature is reached, they behave like brittle materials and are destroyed at a relative deformation of less than 10\%. Impact on cooled parts leads to the destruction of their least durable elementsflash, sprues. Parts are cooled in various ways: by introducing a refrigerant into the treatment zone in the form of carbon dioxide (liquid or solid), liquid nitrogen, or by cooling the chamber with the working medium using a refrigeration unit. Liquid nitrogen has significant advantages. It provides cooling down to a temperature of $-195.8^{\circ} \mathrm{C}$, its supply to the processing zone is not difficult, it is harmless to the environment. The use of liquid nitrogen allows for shorter processing times, higher quality and lower processing costs. For the possibility of successful application in light industry of this method of processing parts, experimental studies of the fragility of the most commonly used polymeric materials were carried out, as well as experimental studies of determining the impact energy required to destroy the flash. The research results can be used at the design stage of the corresponding technological processes for processing polymer parts.

Key words: polymer, brittleness temperature, liquid nitrogen, working capacity. 